\title{
Angora/merino and eri silk: a new union woven fabric for fashion
}

\author{
REENA GARBYAL
}

Received: 09.09.2014; Revised: 12.11.2015; Accepted: 21.11 .2015

Author for Correspondence :

REENA GARBYAL

Department of Clothing and Textiles, College of Home Science, G.B. Pant University of Agriculture and Technology, Pantnagar, U.S. NAGAR (UTTARAKHAND) INDIA Email : reenagarbyal@gmail.com
ABSTRACT : Woven designed fabrics with ecofriendly fibre are more in demand. Now-adays consumer are fashion and health conscious so that they switch towards the ecofriendly fabrics. In this paper, woven designed union fabric has been woven in dobby loom by using twisted angora/merino (38.84 tex), untwisted angora/merino (36.65 tex) and eri silk (27.23 tex) yarns. Total number of 6 union woven fabrics were prepared by using 3 types of design i.e. zigzag, combination of herringbone and basket weave and combination of twill and plain weave from which three union woven fabrics with eri as warp and untwisted angora/merino as weft and three union fabric with twisted angora/merino as warp and eri as weft were made. These designed woven union fabrics were assessed for fashion fabric. It was found that designed union fabrics suitable for apparel purpose.

KEY WORDS: Union fabric, Eri silk, Angora/merino and weave

- HOW TO CITE THIS PAPER : Garbyal, Reena (2015). Angora/merino and eri silk: a new union woven fabric for fashion. Asian J. Home Sci., 10 (2) : 437-441. 